\title{
Assessment of Exposure to Disorders among Building Industry Workers Performing Selected Tasks
}

\author{
Łukasz KUTA ${ }^{1}$, Daniel SZYJEWICZ², Wanda PATRZAŁEK ${ }^{3}$, Kamil GÓRECKI \\ And Iwona RYBKA
}

\footnotetext{
${ }^{1}$ Institute of Environmental Protection and Development, The Faculty of Environmental Engineering and Geodesy, Wrocław University of Environmental and Life Sciences, Wrocław, Poland

${ }^{2}$ Institute of Agricultural Engineering, The Faculty of Life Sciences and Technology, Wrocław University of Environmental and Life Sciences, Wrocław, Poland
}

${ }^{3}$ Institute of Sociology, Department of consumer behavior, University of Wrocław, Wrocław, Poland

Correspondence should be addressed to: Łukasz KUTA ; lukasz.kuta@upwr.edu.pl

Received date: 24 August 2020; Accepted date:17 December 2020; Published date: 19 February 2021

Academic Editor: Irena Figurska

Copyright (C 2021. Łukasz KUTA, Daniel SZYJEWICZ, Wanda PATRZAŁEK, Kamil GÓRECKI And Iwona RYBKA. Distributed under Creative Commons Attribution 4.0International CC-BY 4.0

\begin{abstract}
Work performed in the building industry contributes to the formation of many threats for employees. Microclimate factors, working at heights as well as dangerous substances used in the building space may cause a negative impact on the worker's health. In order to evaluate the safety and comfort of work in the construction industry, a questionnaire consisting of closed and open questions was carried out. The aim of this paper was to assess the level of safety in the construction industry. The study was carried out on construction of buildings in the area of the Lower Silesia Voivodeship. A survey among construction workers was conducted. Based on the studies, a number of factors have been identified that affect the level of occupational health and safety at work. The functional relation between seniority, the employee's age and the length of breaks at work was determined. It turns out that a lack of sufficient breaks during construction works was the main reason for overloading of employees. According to the respondents, the most common symptoms of the neck and lower spine were related to the work performed. In connection with the above-mentioned circumstances, more effective methods of improving the organization and safety of work in this industry should be developed.
\end{abstract}

Keywords: Building, Load, Muscle, Safety

Cite this Article as: Łukasz KUTA, Daniel SZYJEWICZ, Wanda PATRZAŁEK, Kamil GÓRECKI And Iwona RYBKA (2021)," Assessment of Exposure to Disorders among Building Industry Workers Performing Selected Tasks", Journal of Human Resources Management Research, Vol. 2021 (2021), Article ID 921309, DOI: $10.5171 / 2021.921309$ 


\section{Introduction}

The construction industry makes a large contribution to each country's gross domestic product (GDP) (Korkmaz et al., 2018). Work in the construction industry can be classified as one of the most dangerous professions (Ganah et al., 2015). The wide range of work carried out in construction means that many accidents are registered in this industry every year (Latza, 2000). Among the most common causes, organizational, human and technical factors were mentioned (Bust et al, 2005). Poor work conditions directly affect a level of occupational safety and satisfaction while performing the duties of construction workers. The specificity of the construction industry results from its diversity and conditions under which the work was performed (Haslam 2002). Safety is increasingly emphasized as an indicator of success in a construction project (Mahmoundi et al., 2014). Ensuring safety on a construction site is one of the most important elements of the entire project. In addition, providing an accidentfree workplace on the level of occupational safety required the reduction of excessive physical and mental load among the employees (Hansson et al, 2004; Whysall et al, 2006). Current medical studies show that load on the musculoskeletal system is a common and social problem in many countries (Buckle et al, 2002). Many reports determine a wide scale of this problem and the causes of illnesses among manual workers (e.g., farmers) as well as white-collar workers Fabunmi et al., 2005). Musculoskeletal disorders are one of the most common health problems at work and affect millions of employees every year (Boschman et al., 2015). According to a study of the European Foundation for the Improvement of Living and Working Conditions in Dublin, the social costs incurred due to the reduction of diseases in the musculoskeletal system of employees amount to approx. $15 \%$ of the costs of accidents at work. It should be emphasized that about $33 \%$ of manual workers working in the European Union suffer back and spine pain, almost $23 \%$ of respondents complain about general fatigue, and about $13 \%$ feel overload of the hands. Employees in the construction industry were also surveyed (Jarosiewicz, 2006). In their case, the load on the musculoskeletal system may be higher by $16 \%$ compared to other professions (Boschman et al., 2015).

Due to the wide range of work performed by construction workers, repeatability of activities, uncomfortable body position and environmental conditions, construction workers are particularly exposed to musculoskeletal disorders (Stomberg et al., 2010). An important factor affecting the comfort and productivity of construction workers is the ergonomic factor (van der Molen et al., 2005). Proper employee awareness in the aspect of ergonomics lies primarily in the daily work with the use of tools, machines and devices that do not adversely affect comfort and safety at work. Ergonomics is an adaptation of the work environment in which a person works to his physical capabilities (Smith, 2015). It is mainly about designing working elements used on a daily basis to facilitate work as much as possible (Albers et al., 2005; Buckle, 2005). It is also important to reduce injuries resulting from the use of construction tools (Sang, 2008). The disorders of the musculoskeletal system were described by (Bobick et al., 1995; Oude et al., 2011; Murphy et al., 1992) as a very serious social problem, which occurred in many professions. It was mainly observed in the construction industry, where employees were exposed to external loads (Bust et al., 2005; Latza, 2000). So far, many authors have described the methods to improve safety in the construction industry (Moir, 2000). Mobed et al. (Mobed, 1998) paid special attention to the problem of seasonal workers working on US farms. Employees who lived in California often performed very hard work. They had low social status, often a lack of valid health insurance, and significantly limited access to professional healthcare. The work environment in relation to musculoskeletal disorders was described by the physical and psychological factors that accompany the generation of this group. The following elements are characteristic for many physical activities: 
high repeatability of arm and hand movements, uncomfortable body position during work and monotony of movements. In the Polish construction industry, over 1 million workers perform their tasks in an uncomfortable position, and about 0.6 million are exposed to high work monotony. Nearly 1.5 million are forced to carry heavy loads over distances of $10 \mathrm{~m}$. From the presented results it follows that the scale of the occurrence of musculoskeletal disorders is high and therefore, as the authors suggest, more attention should be paid to the conditions in which people work. According to Occhipinti et al. (2007), musculoskeletal disorders may result from a performed task with high repetition frequency, accompanied by a small mass of the operated object. Marras and Schoenmarklin confirmed the thesis that, while performing physical work with a high repetition frequency, a risk of wrist disorders occurs (Marras et al., 1993; Johnston et al., 2005; Sari et al., 2010; Osborne et al. 2007). The particularly high level of this risk concerns women. Particularly dangerous are loads resulting from lifting loads above the human shoulder line (Sluiter et al., 2001). Neck, back, arm and wrist strains are especially dangerous (Hales et al.,1994). Often disorders in the musculoskeletal system result in absence from work (Hansson et al., 2004; Oude et al., 2011; Roelen et al., 2007). They cause very high costs during the recovery of the employee (Szeto et al., 2009). In order to identify the causes of musculoskeletal disorders among construction workers more precisely, a survey was conducted in which the relevant information was obtained.

\section{Methodology}

This paper had qualitative and quantitative features; hence a standardized questionnaire was prepared to collect the needed information. The authors assessed the level of safety and comfort among workers who met some criteria while performing selected works in the building industry. These criteria included: working at least one year in this industry and performing a similar activity in this period. The total number of participants were 160 men. The study was conducted in the Lower Silesia Voivodeship (Poland) on four construction sites. During these studies the workers were asked e.g. about their age, work experience and type of workstation. Information received from the studies was used to develop work instructions and to create preventive actions aimed at improving working conditions by reducing the possibility of hazardous situations in the work environment. The aim of the study was to determine the relationship between age, work experience of the workers and their suggestions regarding determining breaks at work. This approach can lead to improvements in effectiveness and safety during the working day.

The studies were conducted between May and November 2019 on the basis of a prepared questionnaire, the authors' own observations and analysis of reports describing the health level of employees in the building industry. The main research problem in this study was to verify whether it is possible to improve work safety on the construction site. The prepared questionnaire included 17 questions (10 closed and 7 open). The collected items in the survey were: age, work experience, scope of tasks, effort and discomfort level, usability felt, complaints and disorders, time needed for rest within working day as well as body workload connected with a performed task. On the basis of the obtained data, eight groups of workers were selected: drivers (D), roofers $(\mathrm{R})$, plasterers $(\mathrm{P})$, carpenters $(\mathrm{C})$, physical workers (Ph), machine operators (M), steel fixers (Sf) and pavers (Pa). Basic time at work was 8 hours.

An important issue of the studies was to obtain information from the respondents allowing the improving of working conditions and assessment of employee satisfaction obtained from daily work. On the basis of the collected data and relationships between age, work experience and time needed for breaks, an improved schedule of the working day was proposed. Each respondent was asked to assess a pain/dissatisfaction level (PDL) at 
work. Their evaluation ranged from ' 1 ' ("little pain") to '5' ("extreme pain"). Based on this information, the PDISS evaluation for each type of ailment was calculated. In square brackets, an average percentage of pain duration (PAINduration) during work shift was described. All participants were informed about the study aims, and they then declared their participation in this study.

For determining the breaks at work, the following procedures were used;

- For heavy work, the number of breaks should be greater than three during the working day,

- For one break, its time should be set about half of the working day,

- It is preferable to use more breaks, because the effectiveness of breaks decreases when their length increases.

The data were processed in Microsoft Excel. This program enabled the calculation of mean and standard deviation. The t-Student test was used to analyze the differences between workers' answers by means of the STATISTICA 12 program. It was assumed that the difference is statistically significant where $p<0.05 \quad$ ( $p$-value probability). The relationship between the effectiveness of surveyed workers on working time by means of the STATISTICA 12 program was calculated. The accuracy coefficient $\mathrm{R}^{2}$ of the determined function was also determined.

\section{Results}

The structure of examined workstations was dominated by pavers $(25 \%)$, steel fixers (21\%) and machine operators (15\%) (Table 1). The total number of surveyed workers was 160 men. The age of workers ranged from 20 to 60 years. Taking into account the age of workers, the most numerous group of workers was 30-39 years' old, as well as persons with experience between 2-9 years.

Table 1: Description of the surveyed workers

\begin{tabular}{|c|c|c|c|c|c|c|c|c|c|}
\hline \multirow[b]{3}{*}{ Profession } & \multicolumn{7}{|c|}{ Number of workers } & \multirow{2}{*}{\multicolumn{2}{|c|}{$\mathrm{N}=160$}} \\
\hline & \multicolumn{3}{|c|}{ Age (years) } & & \multicolumn{3}{|c|}{ Work experience (years) } & & \\
\hline & $20-29$ & $30-39$ & $40-49$ & $50-60$ & $2-9$ & $10-19$ & $20-30$ & $\mathrm{n}$ & $\%$ \\
\hline $\mathrm{D}$ & 1 & 2 & & & 3 & & & 3 & 2 \\
\hline $\mathrm{R}$ & & 2 & 2 & 2 & 2 & 3 & 1 & 6 & 4 \\
\hline $\mathrm{P}$ & 3 & 3 & 6 & 3 & 5 & 7 & 3 & 15 & 9 \\
\hline $\mathrm{C}$ & & 13 & 5 & 1 & 4 & 12 & 2 & 18 & 11 \\
\hline $\mathrm{Ph}$ & & 11 & 8 & 2 & 12 & 8 & 1 & 21 & 13 \\
\hline M & 5 & 15 & 3 & 1 & 18 & 4 & 2 & 24 & 15 \\
\hline $\mathrm{Sf}$ & 8 & 11 & 10 & 4 & 21 & 8 & 4 & 33 & 21 \\
\hline $\mathrm{Pa}$ & 5 & 25 & 8 & 2 & 23 & 15 & 2 & 40 & 25 \\
\hline Total & 22 & 82 & 42 & 15 & 88 & 57 & 15 & 160 & 100 \\
\hline SD & 2 & 8 & 3 & 1 & 9 & 4 & 1 & & \\
\hline
\end{tabular}

Table 2 presents disorders and complaints as the consequences of daily performed work by surveyed workers. A majority of the respondents indicated pains in the lower part of the spine as well as in the neck. The pavers reported nearly one third of symptoms among all questioned, whereas only nine of the drivers had experienced pain or disorders. 
Table 2: Number of complaints reported by respondents. In brackets, a mean pain/dissatisfaction level (PDISSevaluation) of the respondents was presented. In

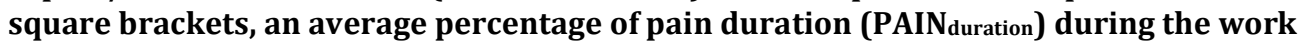
shift was measured.

\begin{tabular}{|c|c|c|c|c|c|c|c|c|c|}
\hline $\begin{array}{l}\text { Type of } \\
\text { aliments }\end{array}$ & D & $\mathbf{R}$ & $\mathbf{F}$ & C & $\mathbf{P h}$ & $\mathbf{M}$ & Sf & $\mathbf{P a}$ & $\begin{array}{l}\text { Total numer } \\
\text { of } \\
\text { respondents }\end{array}$ \\
\hline $\begin{array}{l}\text { Ankles / feet } \\
\text { PDDISS }_{\text {evaluation }} \\
\text { PAIN }_{\text {duration }} \\
(\%)\end{array}$ & - & - & $1(3)[5]$ & - & $1(3)[5]$ & - & - & $2(3)[25]$ & 4 \\
\hline $\begin{array}{l}\text { Knee/s } \\
\text { PDDISS }_{\text {evaluation }} \\
\text { PAIN }_{\text {duration }} \\
(\%)\end{array}$ & - & $2(2)[15]$ & - & - & $2(5)[20]$ & - & - & $\begin{array}{c}9 \\
(4)[25]\end{array}$ & 13 \\
\hline $\begin{array}{l}\text { Thighs / hips } \\
\text { PDDISS } \text { evaluation } \\
\text { PAIN duration }_{\text {(\%) }} \\
\end{array}$ & - & $1(3)[10]$ & $3(2)[10]$ & - & $1(2)[15]$ & - & - & $3(2)[10]$ & 8 \\
\hline $\begin{array}{l}\text { Lower spine } \\
\text { PDDISS }_{\text {evaluation }} \\
\text { PAIN }_{\text {duration }} \\
(\%) \\
\end{array}$ & $6(4)[15]$ & $1(2)[5]$ & $3(4)[15]$ & $3(1)[5]$ & $6(3)[5]$ & $6(2)[10]$ & $3(2)[10]$ & $6(1)[25]$ & 28 \\
\hline $\begin{array}{l}\text { Neck } \\
\text { PDDISS } \text { evaluation } \\
\text { PAIN }_{\text {duration }} \\
(\%) \\
\end{array}$ & $1(2)[5]$ & $2(4)[10]$ & $3(2)[10]$ & $2(2)[15]$ & - & $3(2)[5]$ & $2(1)[5]$ & $6(3)[10]$ & 23 \\
\hline $\begin{array}{l}\text { Elbow/s } \\
\text { PDDISS }_{\text {evaluation }} \\
\text { PAIN }_{\text {duration }} \\
(\%) \\
\end{array}$ & - & $3(2)[30]$ & - & - & $2(1)[5]$ & - & $3(2)[25]$ & $6(2)[10]$ & 14 \\
\hline $\begin{array}{l}\text { Arm/s } \\
\text { PDDISS }_{\text {evaluation }} \\
\text { PAIN }_{\text {duration }} \\
(\%) \\
\end{array}$ & $2(1)[5]$ & $2(3)[10]$ & $1(2)[40]$ & $2(2)[25]$ & - & $4(1)[5]$ & $3(2)[5]$ & $5(2)[15]$ & 15 \\
\hline $\begin{array}{l}\text { Wrist/s } \\
\text { PDDISS }_{\text {evaluation }} \\
\text { PAIN }_{\text {duration }} \\
(\%) \\
\end{array}$ & - & - & - & - & $2(2)[5]$ & - & $4(2)[20]$ & $2(4)[25]$ & 8 \\
\hline $\begin{array}{l}\text { Muscle } \\
\text { stiffness } \\
\text { PDDISS }_{\text {evaluation }} \\
\text { PAIN }_{\text {duration }} \\
(\%)\end{array}$ & - & - & $1(1)[35]$ & $2(2)[25]$ & $2(4)[5]$ & - & $3(3)[5]$ & - & 8 \\
\hline $\begin{array}{l}\text { Tingling in the } \\
\text { limbs } \\
\text { PDDISS }_{\text {evaluation }} \\
\text { PAIN }_{\text {duration }} \\
(\%)\end{array}$ & - & $\begin{array}{l}2(1) \\
{[10]}\end{array}$ & $1(2)[5]$ & $1(5)[5]$ & - & - & - & $5(4)[15]$ & 9 \\
\hline Total & 9 & 11 & 9 & 10 & 22 & 13 & 18 & 44 & 124 \\
\hline
\end{tabular}

* respondents could indicate more than 1 answer 
On the basis of statistical analysis, it was found that the results including assessment between analyzed professions differ significantly from each other by $\mathrm{p}=0.0000004$ $(\mathrm{p}<0.05)$.

\section{Assessment of body-posture load of the employees while performing selected activities in the building industry}

Many different tasks performed during the working day as well as a wide range of held postures were observed (Table 3). The most numerous workers held an uncomfortable bent and twisted position which resulted e.g., from laying paving stones (paver). The smallest group of men used a shovel during their work. Some workers maintained a different position during the working day; for instance, they lifted heavy objects of various shapes and dimensions, while adopting an uncomfortable position, for instance, standing or sitting without the possibility of changing body position.

Table 3: List of the tasks or workers' positions taken during working day

\begin{tabular}{|l|l|l|}
\hline Task/Postures & N & \% \\
\hline Lifting & 11 & 6 \\
\hline Pushing the object & 4 & 2 \\
\hline Bending the torso & 14 & 8 \\
\hline Digging with a shovel & 1 & 1 \\
\hline Lifting heavy objects often in an uncomfortable position & 6 & 3 \\
\hline Many hours work in a sitting position (without the ability to change position) & 12 & 7 \\
\hline $\begin{array}{l}\text { Many hours work in a standing position (without the possibility of changing } \\
\text { the position) }\end{array}$ & 10 & 5 \\
\hline Many hours work in the neck inclination & 12 & 7 \\
\hline $\begin{array}{l}\text { Many hours work in the kneeling position (without the possibility of } \\
\text { changing the position) }\end{array}$ & 11 & 6 \\
\hline Many hours work in the squat (similar position) & & \\
\hline Frequent twist of the torso & 9 & 5 \\
\hline Doing work in position with a bended or twisted torso & 17 & 9 \\
\hline Work in a position with bend or pulled head & 19 & 10 \\
\hline Work with arms raised above shoulder joints & 21 & 11 \\
\hline Work with excessively bent or twisted wrists & 8 & 4 \\
\hline Work with a high degree of repeatability (>5 times per minute) & 18 & 10 \\
\hline Total & 11 & 6 \\
\hline
\end{tabular}

* respondents could indicate more than 1 answer

Among the solutions that could reduce the level of disorders or complaints resulting from work activities, respondents most often indicated a need to use a 30-minute break in the middle of work time. Undoubtedly, such an approach including longer breaks could result in improved work efficiency (Fig.1). 


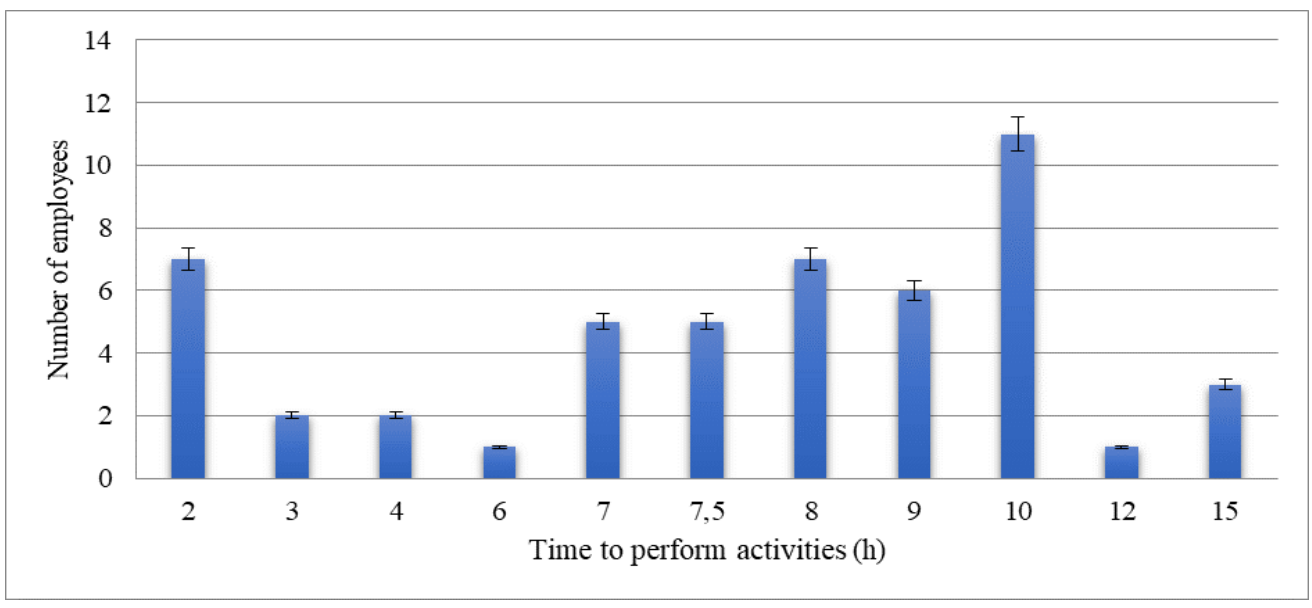

Fig. 1: Estimated time for performing required tasks during work shift reported by workers

As many as $48 \%$ of respondents declared that they perform a required task during one work shift (8-10 hours), another $26 \%$ for a given activity need 8-9 hours, and 8\% of respondents took 12-15 hours.
Necessary time for rest in the opinion of $48 \%$ of respondents should take $10-20$ minutes, $16 \%$ confirmed that it should be longer than 30 minutes, or even 60 minutes (Fig.2).

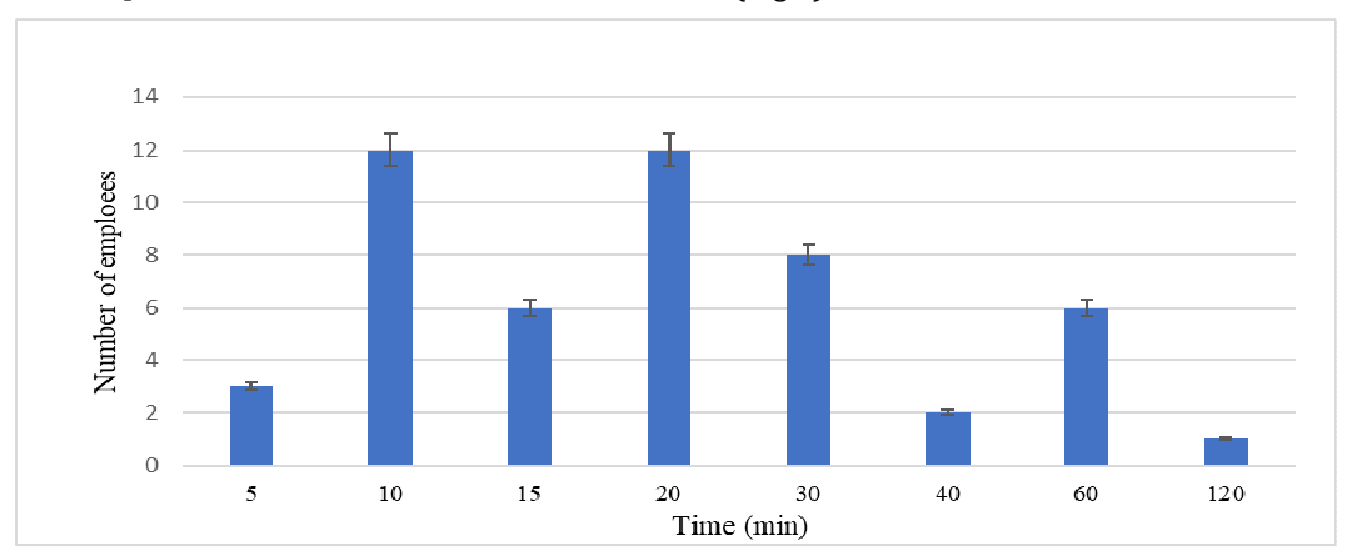

Fig. 2: Time for rest during shift work, expected by the respondents

The minimum time for recovery depends on the age of the respondent and increases especially in the range of 48-55 years of age and differed from 60 to 120 minutes. Younger employees up to the age of 35 , for a minimum regeneration time, declared nearly 20 minutes (Fig. 3). It increased particularly sharply among more experienced employees (over 25 years of work) and ranged from 60 to 90 minutes. It is more diversified among employees with an average length of employment (7-15 years) and definitely decreased among employees who had worked for up to 5 years and results in only 10 minutes per 8 hours. 


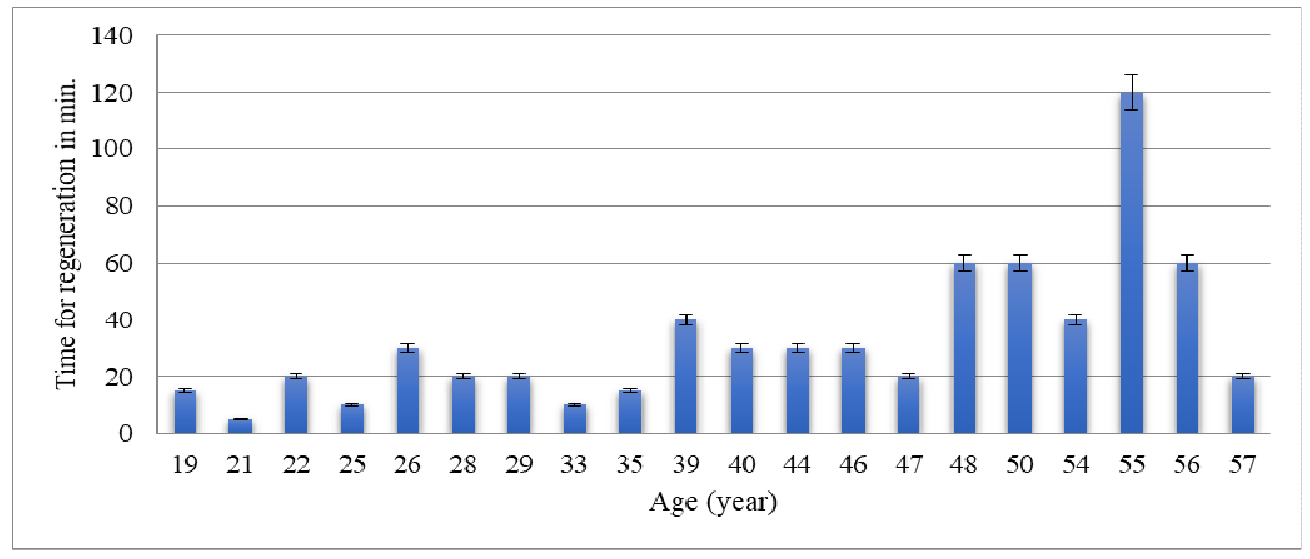

Fig.3: Time for rest according to the workers' opinions in relation to their age

Figure 4 (a-g) presents the courses of workers' effectiveness (a ten-point scale) at work resulting from time of work (range 18 hours) based on the opinions of the respondents in the building industry. From these figures, it can be shown that comfort decreases during the next working hour. Poor effectiveness of work was observed between the fifth and sixth working hours, when starting work at $8.00 \mathrm{am}$. The highest comfort at work occurred from 10.00 am to 11.00 am. During an eight-hour working day, the pace was at its lowest. Based on this information, the organizational aspect of the work should be improved. The best solution could include a modified schedule of breaks during the working day. a)

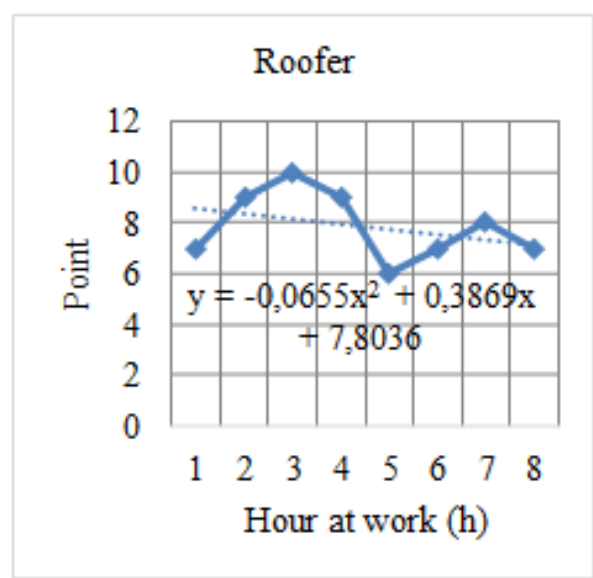

c)

b)

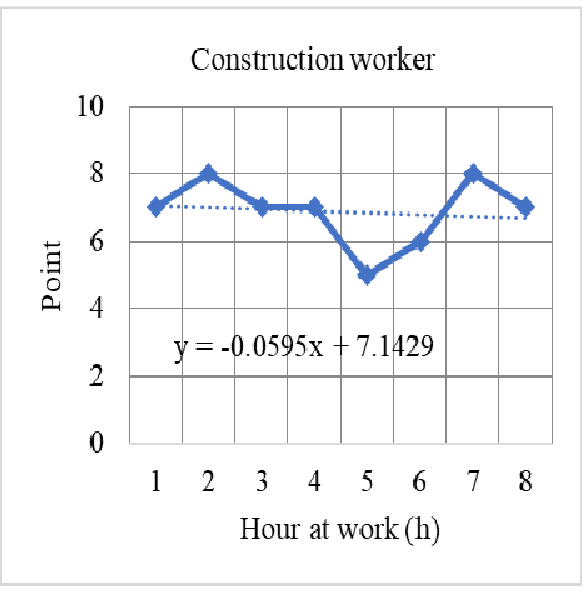

d) 


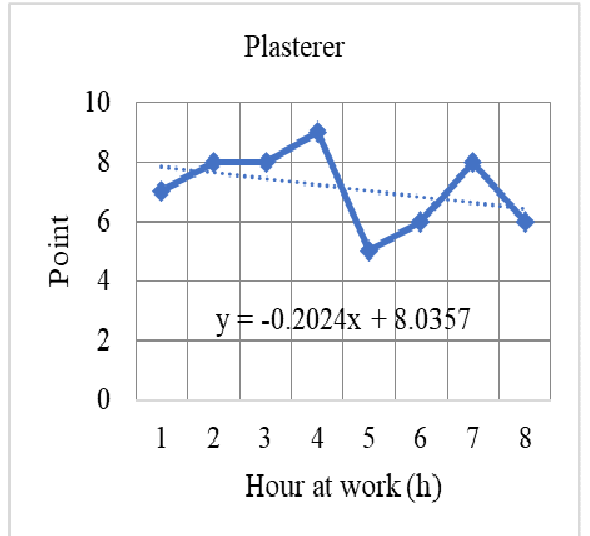

e)

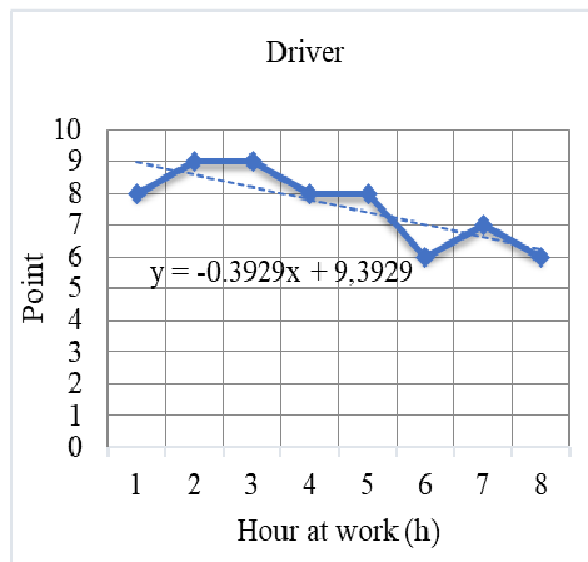

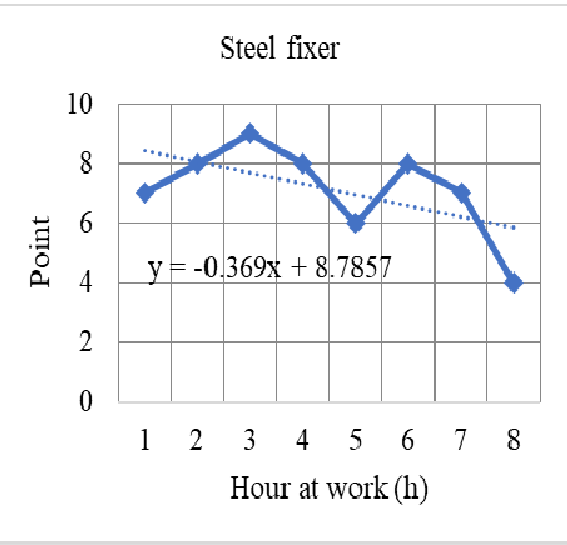

f)

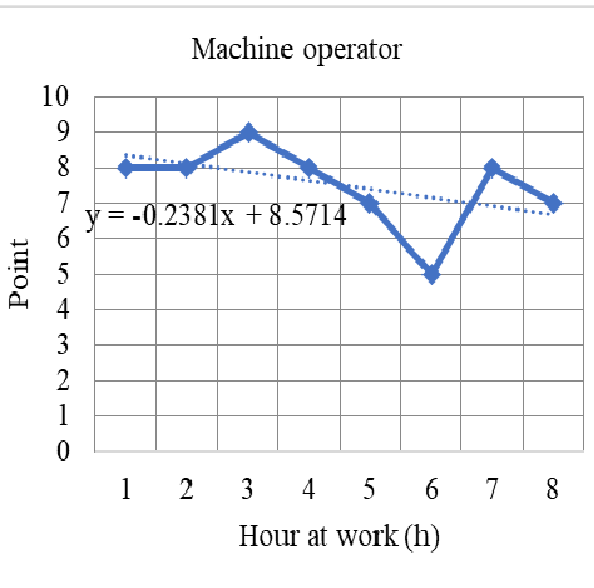

g)

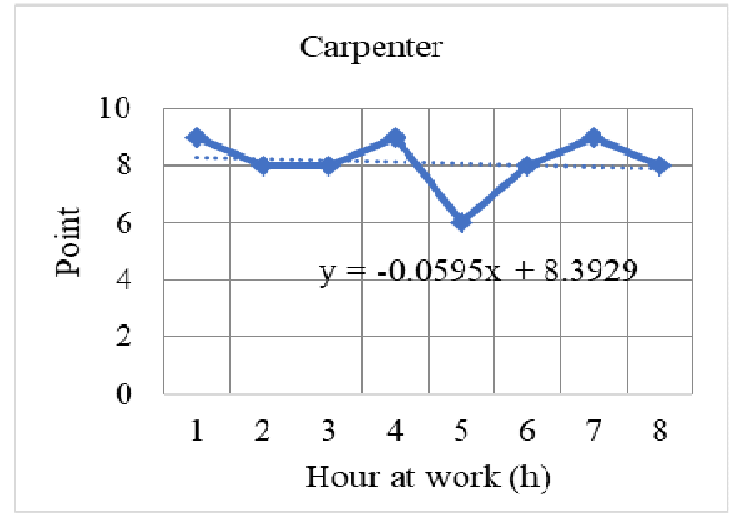

Fig. 4: (a-g). Assessment of work efficiency declared by workers in relation to a moment at work: a) roofer, b) construction worker, c) plasterer, d) steel fixer, e) driver, f) machine operator, g) carpenter 
Figure 5 (a-d) presents an evaluation of work comfort and effectiveness according to the workers' opinions while working overtime. Based on the obtained results, only the drivers, plasterers, physical workers, machine operators and pavers worked overtime. There were consequences of technological processes and work organization on the construction site. In some cases, the total time at work exceeded 13 hours. a)

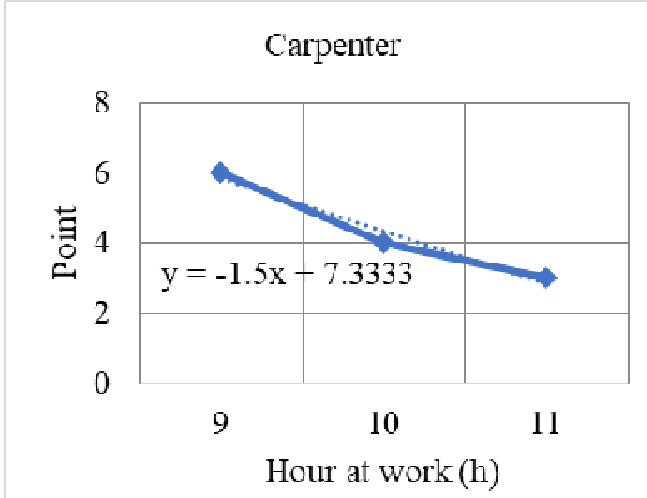

b)

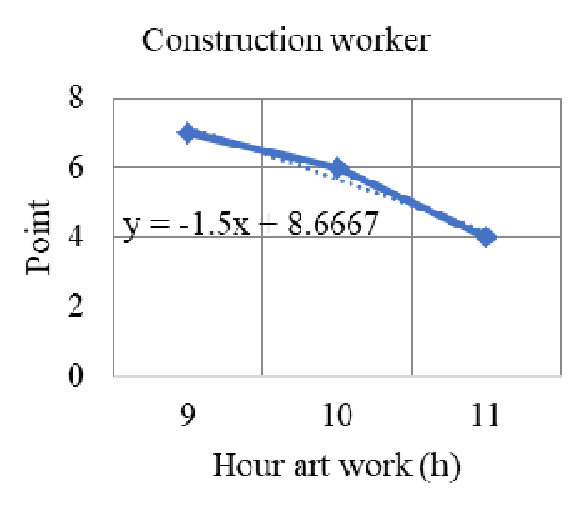

c)

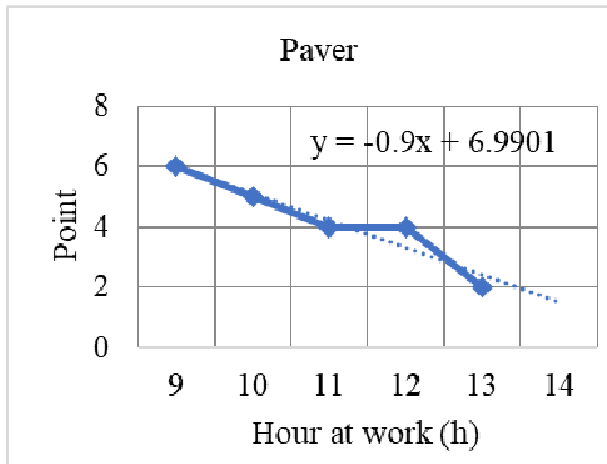

d)

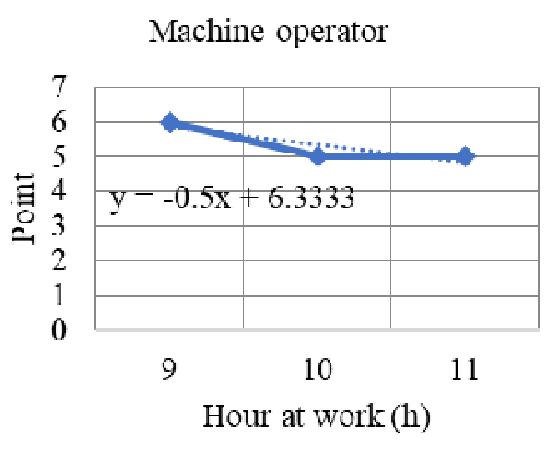

Fig. 5: (a-d). Assessment of work efficiency while working overtime: a) carpenter, b) construction worker, c) paver, d) machine operator

\section{Determining breaks during the working} day

Among the solutions which could reduce the level of complaints and risk of disorders resulting from performed work, respondents most often indicated the need to use the right moment for a break during a shift. Based on these expectations and the author's own observations, it was proposed that there should be a schedule of the rests during the working day (1-8 hours) and during overtime. 
Based on the circumstances as well as the procedures listed in the methodology

chapter, the breaks were worked out. The schedules were presented in Figures 6 - 7.

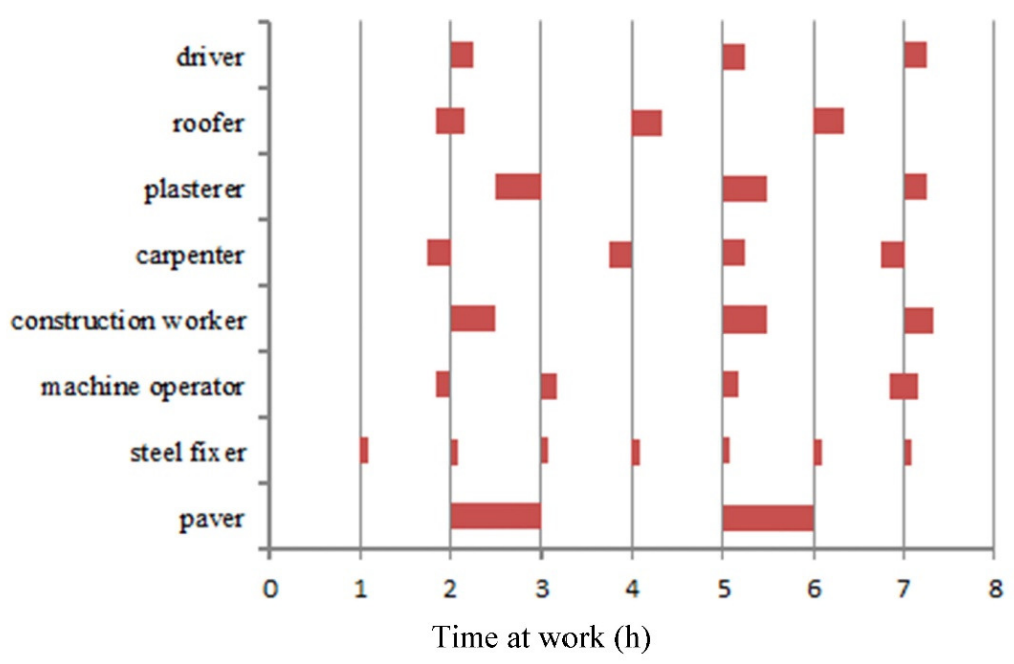

Fig. 6: Proposed distribution of the breaks during the working day for all groups of workers

Repetitive tasks as well as work organization required the preparation of some specific solutions. For instance, in order to reduce the monotony of steel-fixer workers, it was proposed that there should be a 5-min break after each performed hour. Due to working at heights, three breaks for a roofer have been proposed.
The basic rule in designing breaks was a period in which the effectiveness of workers decreased. A similar approach was used for workers who worked overtime. Usually, the physical workers were the longest at work, hence breaks after each hour at work were proposed.

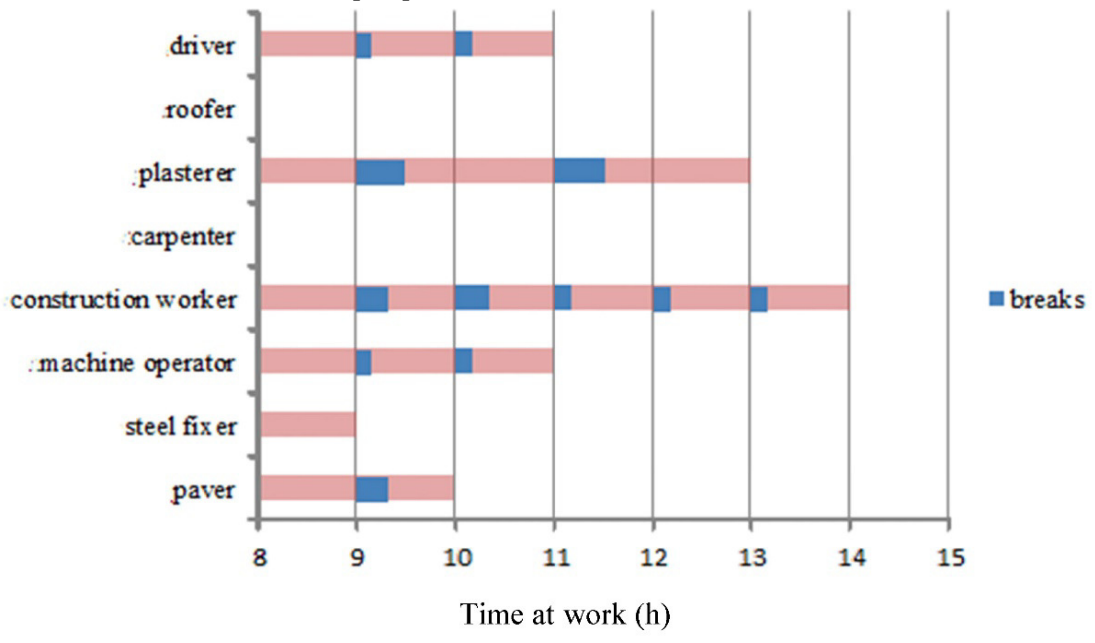

Fig. 7: Proposed distribution of the breaks during overtime work for selected groups of workers 
The tasks of the building industry require the use of workers' physical force, hence in order to minimize a risk of musculoskeletal disorders or pain development it is obvious that it is necessary to ensure the right level of comfort of work and organizational issues during the working day.

\section{Discussion}

According to van Tulder et al. 1995 and Silverstein et al. 1997 (van Tulder et al., 1995; Silverstein et al., 1997), activities involving overcoming musculoskeletal disorders require high financial outlays. The health problems related to the overloading of construction workers also appeared in the Netherlands. The local Ministry of Social Affairs promotes activities to improve work safety on construction site (Arbo, 2006). As emphasized by Gillen et al., (2004) and van der Molen et al., (2005), very often employers do not have sufficient funds for preventive actions or do not engage in cooperation with entities that provide technical solutions in the field of safety and ergonomics of work in the market. Referring to the research conducted among Dutch masons, it should be noted that about $45 \%$ of them suffer from ailments in the lumbar region of the spine and, in the shoulder area, about 27\% (van der Molen et al., 2005). In the conducted research, $25 \%$ of workers felt pain in the lower part of the spine, while about $5 \%$ complain of shoulder pain. The most frequent external load during such work was in the range of 1-6 kg. The total working time in an uncomfortable body position was over 4 hours a day. A significant external burden also occurs during surgeons' work, especially during operations on patients. This is mainly due to the lack of a break during the procedure (Slack et al., 2008). It is necessary to introduce breaks because they will avoid medical errors and eliminate mental and physical overload (Geurts et al., 2006). Research conducted by Hassan and Abou El-Soaud (1997) among physical workers in the IT industry confirmed that the areas most exposed to pain and musculoskeletal disorders are the shoulders and neck ( $66.7 \%$ of the subjects) and the lower part of the spine $33 \%$ of people). The authors pointed out that static loads combined with dynamic loads such as wrists are particularly dangerous because in many cases they end with employee injuries. As a consequence, symptoms of dysfunctions of the nervous and circulatory systems of these employees often appear. According to the authors, if employees will follow the rules of working hours and breaks at work, the level of work safety will be satisfying.

\section{Summary}

Based on conducted studies in the real work environment, it was found that more frequent breaks for industry workers should be introduced. A positive correlation was prepared between the seniority of industry workers and the time needed to regenerate during described works. In the 48-58 age group, a reasonable break-time duration should be a total of 120 minutes, hence 15 minutes after each work hour. Workers aged 20-30 have confirmed that their time to regain their strength is 20 minutes over an 8-hour working period. Despite many organizational and technical solutions, as well as applied individual protection solutions, there are a number of risks in the industry space that impact negatively workers' health and life, which result in disorders of the musculoskeletal system in the cervical and lumbar parts, which may lead to the development of occupational diseases and result in time off work. As demonstrated during twenty-four hours, industry workers performed their activities for up to 12 hours per day, which additionally affects the overload of the musculoskeletal system.

\section{References}

- $\quad$ Albers, J., Estill, C. and MacDonald, L. (2005), 'Identification of ergonomics interventions used to reduce musculoskeletal loading for building installation tasks', Applied Ergonomics, 36, 427-439. 
- Arbo Platform. Nederland: Europees Agentschap voor veiligheid en gezondheid op het werk: Arboconvenanten Bouw; c2003-2007 [online]. Netherlands: European Agency for Safety and Health at Work. Available from: http://www.arbo.nl/systems/strategie s/covenants 2006 .

- Bobick, TG. and Myers, JR., (1995), 'Back injuries in Agriculture: Occupations Affected. CRC Press,' Lewis Publishers, Boca Raton.

- Boschman, JS., Frings-Dresen, MHW. and van der Molen, HF., (2015), 'Use of Ergonomic Measures Related to Musculoskeletal Complaints among Construction Workers: A 2-year Follow-up Study,' Safety and Health at Work, 6, 90-96.

- Buckle, P. (2005) 'Ergonomics and musculoskeletal disorders,' Occupational Medicine, 55, 164-167.

- Buckle, PW. and Devereux, JJ. (2002), 'The nature of work-related neck and upper limb musculoskeletal disorders,' Appl Ergon., 32, 207-217.

- $\quad$ Bust, PD., Gibb, AGF. and Haslam, R.A. (2005), 'Manual handling of highway kerbs - focus group findings,' Applied Ergonomics, 36(4), 417-426.

- Chung, K. (2006), 'Current Status of Outcomes Research in Carpal Tunnel Surgery,' Hand(NY), 1(1), 9-13.

- Courvoisier, DS., Genevay, S. and Cedraschi, C. (2011), 'Job strain, work characteristics and back pain: a study in a university hospital,' Eur J Pain, 15(6), 634-640.

- Fabunmi, AA., Aba, So. and Odunaiya, NA. (2005), 'Prevalence of low back pain among peasant Farmers In A Rural Community In South West Nigeria,' Afr J Med Sci, 34(3), 259-262.

- Geurts, SA. and Sonnentag, S. (2006), 'Recovery as explanatory mechanism in the relation between acute stress reactions and chronic health impairment' Scand J Work Environ Health, 32(6), 482-492.

- Ganah, A. and John, GA. (2015), 'Integrating Building Information Modeling and Health and Safety for
Onsite Construction,' Safety and Health at Work, 6, 39-45.

- Gillen, M. (2004), 'Construction managers' perceptions of construction safety practices in small and large firms: A qualitative investigation,' Work, 23, 233-243.

- Hassan, AA. and Abou El-Soaud, A.M. (1997), 'Workrelated shoulder-neck disorders among different occupational groups,' Egyptian Journal of Occupational Medicine, 21(1), 73-84.

- Hales, TR., Sauter, SL., Peterson, MR., Fine, LJ., Putz-Anderson, V. and Schleifer, L.R. (1994), 'Musculoskeletal disorders among visual display terminal users in a telecommunications company,' Ergonomics, 37(10), 1603-1621.

- Haslam, RA. (2002), 'Targeting ergonomics interventions - learning from health promotion,' Applied Ergonomics, 33, 241-247.

- Hansson, T. and Jensen, I. (2004), 'Sickness absence due to back and neck disorders,' Scand J Public Health Suppl, 63, 109-151.

- Jarosiewicz, G. (2006), 'Deseases of the musculoskeletal system,' Departament of work condition. IP, 4, 18-20.

- Korkmaz, S. and Park, D. J. (2018), 'Comparison of Safety Perception between Foreign and Local Workers in the Construction Industry in Republic of Korea,' Safety and Health at Work, 9, 53-58.

- Johnston, WK. III, Hollenbeck, BK. and Wolf, J.S. (2005), 'Comparison of neuromuscular injuries to the surgeon during hand-assisted and standard laparoscopic urologic surgery,' $J$ Endourol,19(3), 377-381.

- Latza, U. (2000), 'Cohort study of occupational risk factors of low back pain in construction workers,' Occupational and Environmetnal Medicine, 57, 28-34.

- Mahmoudi, S. and Ghasemi, F. (2014), 'Framework for Continuous Assessment and Improvement of Occupational Health and Safety Issues in Construction Companies,' Safety and Health at Work, 5, 125-130. 
- Marras, W.S. and Schoenmarklin, R.W. (1993), 'Wrist motions in industry,' Ergonomics, 36, 341-351.

- Mobed, K., Gold, E. and Schenker, M. (1998), 'Occupational health problems among migrant and seasonal farm workers,' West J. Med., 157(3), 367- 37.

- Moir, S. (2000), 'Making sense of highway construction: A taxonomic frame-work for ergonomic exposure assessment and intervention research,' Applied Occupational and Environmental Hygiene, 18(4), 256267.

- Murphy, D.J. (1992), 'Safety and Health for Production Agriculture,' American Society of Agricultural Engineers. Books \&amp; Journals.

- Occhipinti, E. and Colombini, D. (2007), 'Updating Reference Values and Predictive Models of the OCRA Method in the Risk Assessment of WorkRelated Musculoskeletal Disorders of the Upper Limbs,' Ergonomics, 50(11), 1727-1739.

- Osborne, RH., Nikpour, M., Busija, L., Sundararajan, V. and Wicks, IP. (2007), 'Prevalence and cost of musculoskeletal disorders: a population-based, public hospital system healthcare consumption approach,' J Rheumatol, 34, 24662475.

- Oude Hengel, KM., Visser, B. and Sluiter, JK. (2011), 'The prevalence and incidence of musculoskeletal symptoms among hospital physicians: a systematic review,' Int Arch Occup Environ Health, 84(2), 115-11.

- Roelen, CA., Koopmans, PC., de Graaf, JH., van Zandbergen, JW. and Groothoff, J.W. (2008), 'Job demands, health perception and sickness absence,' Occup Med., 57(7), 499-504.

- Sang, D. (2008), 'Investigation of Ergonomic Issues in the Wisconsin Construction Industry,' The journal of SH\&E research, (5).

- Sari, V., Nieboer, TE., Vierhout, ME., Stegeman, DF. and Kluivers, K.B. (2010), 'The operation room as a hostile environment for surgeons: physical complaints during and after laparoscopy,' MinimInvasive Ther Allied Technol, 19(2), 105-109.

- $\quad$ Silverstein, B.A. (1997), 'Work-related musculoskeletal disorders: Comparison of data sources for surveillance,' American Journal of Industrial Medicine, 31, 600-608.

- Smith, M., Ergonomics, http://www.docstoc.com/docs/75382 729/ErgonomicsIssues-RegardingText-Messaging-and-PDA-Use 2011.

- Stomberg, MW., Tronstad, SE. and Hedberg, K. (2010), 'Work-related musculoskeletal disorders when performing laparoscopic surgery,' Surg Laparosc Endosc Percutan Tech, 20(1), 49-53.

- $\quad$ Slack, PS., Coulson, CJ., Ma, Webster, K. and Proops, DW. (2008), 'The effect of operating time on surgeon's muscular fatigue,' Ann R Coll Surg Engl, 90(8), 651-657.

- Sluiter, JK., Rest, KM. and FringsDresen, MHW. (2001), 'Criteria document for evaluating the workrelatedness of upper-extremity musculoskeletal disorders,' Scandinavian Journal of Work, Environment \& Health, 27 (1), 1-102.

- Szeto, GPY., Ho, P., Ting, ACW., Poon, JTC., Cheng, SWK. and Tsang, RCC. (2009), 'Work-related musculoskeletal symptoms in surgeons,' J Occup Rehabil, 19(2): 175-184.

- van Tulder, MW., Koes, BW. and Bouter, LM. (1995), 'A cost-of-illness study of back pain in The Netherlands,' Pain, 62, 233-240.

- $\quad$ van der Molen, HF., Sluiter, JK., Hulshof, CT., Vink, P. and Frings-Dresen, MH. (2005), 'Effectiveness of measures and implementation strategies in reducing physical work demands due to manual handling at work,' Scandinavian Journal of Work, Environment and Health, 31(2), 75-87.

- Whysall, ZJ., Haslam, C. and Haslam, RA. (2006), 'A stage of change approach to reducing occupational ill health,' Preventive Medicine, 43, 422428.

- Van der Molen, HF. (2005), 'Ergonomics in building and construction: time for implementation 
[editorial],' Applied Ergonomics, 36, 387-389

- Van der Molen H., Grouwstra R., Kuijer P., Sluiter J. and Frings-Dresen M. (2004), 'Efficacy of adjusting working height and mechanizing of transport on physical work demands and local discomfort in construction work,' Ergonomics, 47(7), 772-783, DOI: 10.1080/0014013042000193309. 